\title{
Optimizing Waqf Management for Demographic Bonus in Indonesia
}

\author{
Dianidza Arodha \\ UIN Jember, Indonesia \\ arodhamine@gmail.com
}

Ayman

International Open University Jeddah, Jeddah

aymansofyan96@gmail.com

\begin{abstract}
Indonesia will in the demographic bonus which has a good and bad impact on economic development. Either impacts, Central Bureau of Statistics (BPS) of Indonesia launched that the latest data stated the amount of unemployed per February 2019 declined. The existence of productive waqf gives a great prospect to solve the negative impact of demographic bonus in Indonesia. Until now, the Indonesian government actives to promote a productive waqf as an instrument of economic welfare. Despite having a high potency, it still has many obstacles in its realization, likes low literary about productive waqf, human resources, etc.. both of them, demographic bonus and waqf can be synergized. Therefore, this study tries to explain the implementation of a government productive waqf in Indonesia. This paper finds a waqf linked Sukuk and micro waqf bank are the big potency can synergy with millennial in demographic bonus in Indonesia.
\end{abstract}

Keywords: Demographic bonus, economic development, productive waqf, waqf linked Sukuk.

\section{Introduction}

Islam did not only came to regulate the life of worship, but also the rules relating to mu'amalah. The rule was made with the aim of the welfare of ummah.

Although it is still not achieved perfectly. Islam has also regulated welfare through various instruments of mu'amalah. If it is implemented comprehensively and properly monitored, prosperity will be achieved as in countries that apply the instruments of mu'amalah Islam in the governance systems of their country.

Indonesia, as a country with a majority Muslim, should be able to achieve prosperity. However, the reality is far from that. The level of welfare is not still being reached. Moreover, your Islamic instruments also have not been maximized in their application. For example the economy of ZISWAF (Zakat, Infaq, Shodaqoh, and Waqf). The potential of ZISWAF in Indonesia is very large, directly proportional to a large number of population in Indonesia. Unfortunately not empowered. The most basic cause is public knowledge about ZISWAF itself.

There was a re-examination towards waqf assets such as the role of waqf in the socioeconomic advancement of the ummah in the past, the existence of vast amounts of waqf assets currently being neglected, the in-efficient administration and management of waqf institutions, and the current development in Islamic finance and economics (Ajeng, 2017). 
Waqf has played a significant role throughout Islamic history towards enhancing the social and economic status of Moslem societies.

Currently, Indonesia has been establishing the formal council for waqf affairs since 2004 as the concrete form of the mandate within the Undang-undang Nomor 41 Tahun 2004, namely Badan Wakaf Indonesia (BWI). This council has the authority to take hold of the whole affair regarding waqf in Indonesia. Generally, BWI provides three categories of waqf services, that are 1) waqf in moving objects, 2) waqf inland, 3) waqf in cash. The main concerns of BWI are more likely in waqf of land and cash.

Most of the land waqf assets that exist, has not been being cultivated productively. Most of nadzir only use the land waqf to build mosque, cemetery, orphanage, and so on. According to Choudury (2012) since the waqf is not only related to economic, political, community, educational, and social development.

The Islamic Development Bank (IDB) describes, in its organization profile, that as an international body, it has established the World Waqf Foundation (WWF) in 2001, in collaboration with waqf institutions, governmental organizations, NGOs, and philanthropists from private sector, to promote waqf to contribute to the development of cultural, social, and economic of the member countries, as well as to alleviate poverty and to extend technical assistance and support to waqf institutions (Norhaliza and Mohammed, 2009).

Many scientific papers that explain how the management of waqf, financial endowments, and the application of waqf directly, whereas the problem that can be generalized is the role of the government to resolve fundamental issues regarding the application of waqf in revitalizing the endowment institutions. (Cajee, 2007; Ayedh; Shafii, Iqbal, Tademir, 2015). In recent years, endowments have been promoted to support instrument economic growth.

Indonesia should be able to work on maximizing waqf to increase economic growth. Moreover, currently, Indonesia is in a condition where there are a large number of productive citizens (called demographic bonus) (Wisnumurti, Darma, Suasih, 2018).

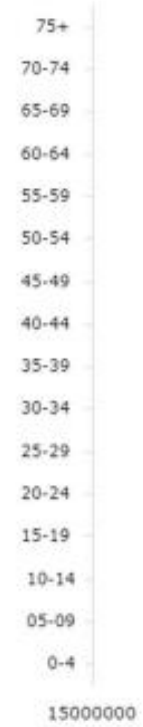

Dkatadata .

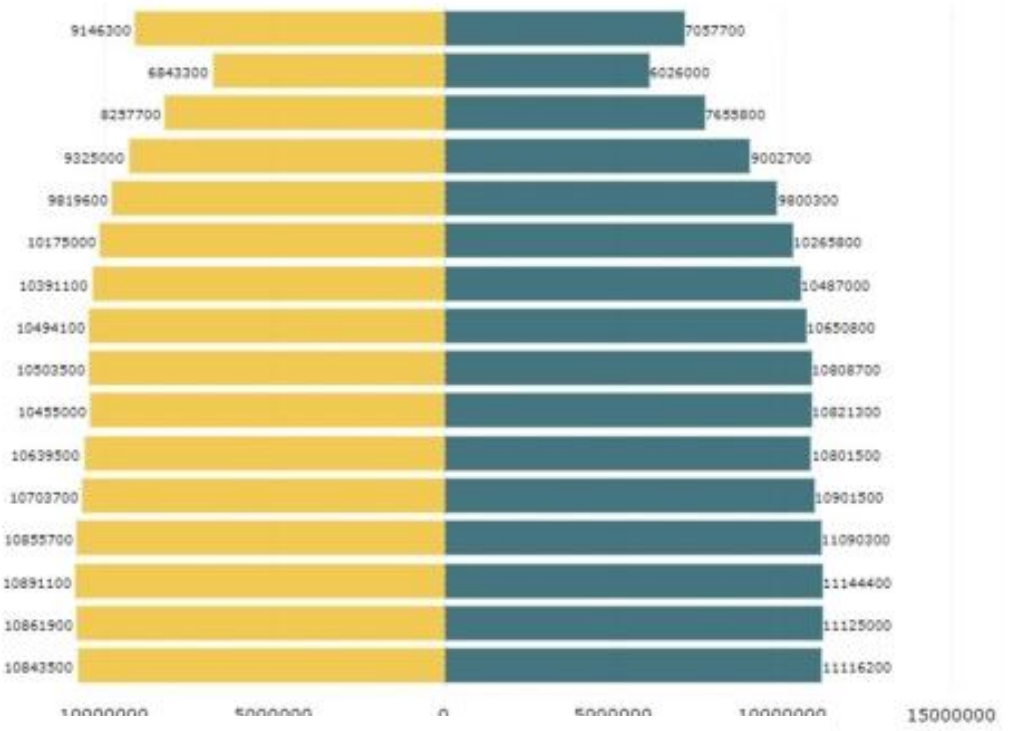

Figure 1. Total Population by Age

Source: BPS, (2018); Katadata (2018).

The picture above shows that, in 2045, Indonesia will be filled with a productive age, this is what will be called a demographic bonus. This demographic bonus is an opportunity to maximize the role of productive populations in the country's economic development. One of them participates in making the endowments available to the community to be part of the 
management of endowments. Bearing in mind, BPS (2018) stated the Indonesian ratio is still 0.389 .

It is hoped that when the demographic bonus phase enters, economic growth will continue, income per capita will increase, and the production sector will also increase rapidly (Dewi, 2015).

This paper tries to review how the implementation of waqf in daily life in the form of Sukuk linked waqf and micro waqf banks in Indonesia. So in the end, if it is considered effective, it can become a role model or be an evaluation for researchers and Indonesia itself.

\section{Overview of Awqaf Potential in Indonesia}

Central bank of Indonesia (2016) published that the development of waqf regulations in Indonesia has existed since pre-colonial times or since the Islamic era existed. The practice of waqf at this time was regulated by customary law which was not yet written but remained by Islamic teachings. Continues to the Dutch colonial period which began to use black and white in the management of waqf property. Then in the old order until the reformation period, endowments began to be regulated in the law, and now in more detail.

At present, Indonesia will enter into a profitable demographic bonus if it is linked to the application of waqf as a productive instrument. If so far, according to BPS (2018), the results of the inter-census population survey (SUPAS) of Indonesia's population reached 264.16 million. It is estimated that in 2045 the population will reach 318.96 million. With a productive population (15 - 64 years) reaching $65.2 \%$.

As reported by wartaekonomi.id (2019), it is stated that the Indonesian Ulema Council (MUI) Endowment Institute considers the potential of endowments in Indonesia to be very large. Considering the report shows assets of cash waqf per year reached more than Rp 100 trillion, with the realization of around Rp 400 billion in 2018.

The calculation is based on the estimation of the Indonesian Waqf Board with the assumption that 100 million citizens endow 100 thousand per month. But in the implementation, according to Pungky Sumadi (representative of the National Committee for Islamic Finance), two things cause suboptimal use of waqf. First is low socialization. Second is poor management ability. On the other hand, President Director of PT Bank BNI Syariah, Imam Teguh Saptono, is optimistic that the potential for waqf can sustain the economy. The potential number of waqf land in Indonesia reaches 4.2 billion square meters or around 420,000 hectares with a value of around Rp 377 trillion.

\section{Optimizing Waqf Implementation in Indonesia}

The practice of waqf has been known since the beginning of Islam. In Islamic historical records, cash waqf has been practiced since the beginning of the second century Hijriyah. Endowments of money were also known during the Ayyubid Dynasty in Egypt. In this modern era, money waqf has become popular thanks to M. A. Mannan with the establishment of a SIBL (Social Investment Bank Limited) institution in Bangladesh which introduced the world's first cash waqf certificate (Hasan, 2010).

Ahmed (2011) and Kahf (2004) suggest a model of a waqf, based on Islamic microfinance institutions to serve the poor, which would be capitalized by cash waqf. Considering that the potential for waqf money in Indonesia is quite large, the government has begun to accommodate its development efforts. Presence of Law No. 41 of 2004 and Government Regulation Number 42 of 2006 became a definite legal basis, public trust and protection of waqf assets. Some rules regarding money endowments include a) Cash Waqf can be done through Islamic Financial Institutions (LKS) appointed by the minister, b) Questions of wakif wishes about money waqf must be written, c) LKS issues certificates of 
money submitted to wakif and nazhir as evidence submission of waqf property, d) LKS on behalf of Nazhir registers waqf items in the form of money to the Minister of Religion (Shafi, Iqbal, Tasdemir, 2015).

Yuliani (2017) concludes that there are two sub-optimal waqf management problems in Indonesia, that is internal problems and external problems. Hamzah (2016) said four factors affect waqf management including aspects of human resources, institutional aspects, government aspects, and geographical aspects. While the study of Saifuddin et al (2014) said there were three issues in the implementation of waqf in Malaysia, that is clarification on the development of waqf based on Islamic academic opinion, obstacles to legislation, and the problem of the administration of Baitul Maal which was inefficient and systematic.

Indonesia is currently trying to develop funding instruments through national sharia securities or state Sukuk. Where this Sukuk is associated with a waqf agreement. In a Reuters report (2016), one of the top global Sukuk market countries in 2016 was Indonesia. With the issuance, it reached USD 7.4 billion.

This state Sukuk has at least four roles, according to the Ministry of Finance, namely: 1) Providing alternative financing for the State Budget, 2) Providing sharia-based investment and liquidity instruments, 3) Developing Islamic financial markets, and 4) Providing benchmarks for corporate Sukuk issuance.

Waqf linked the Sukuk scheme in a press statement of the Ministry of Finance (2018), namely the Indonesian Waqf Institution (BWI) as the manager of waqf funds investing waqf funds in State Sukuk. Furthermore, the return from the State Sukuk yields is channeled by BWI through the Nadzir Distribution Partners for social activities and for financing social infrastructure projects that will become endowments assets. At the reached date of the Sukuk Negara, the repayment cash is returned by BWI to the endangers $100 \%$.

According to Gonzales (2003), and endowment value will be measured by the public and donors in terms of an organization's outputs and impact. This is regardless of whether the money came from the endowment, leveraged funds or operating funds. Without good management systems and performance, the targeted output will never be satisfactory. If the orientation of institution are output and attains its targeted impact, it will attract donors and sustain its beneficiaries.

Figure 2 shows the scheme endowment management, especially waqf implementation.

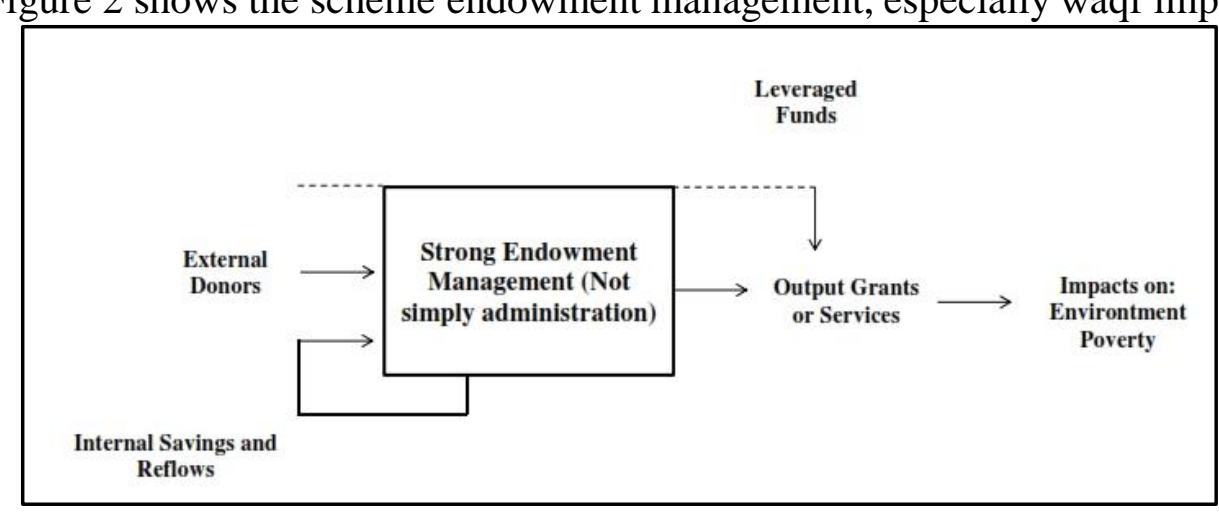

Figure 2. The Endowment Management

Source: Gonzales, (2003)

So great are the benefits and benefits of waqf for human life and improvement of living standards and welfare in the nation and state. Just an example of the success of Muslim countries in Saudi Arabia that use the results of waqf to help build the two holy cities of Mecca and Medina. Likewise, Singapore used the musyarakah Sukuk financing by 
establishing cooperation between other investors with waqf funds and the Singapore Ugama Islamic Council (MUIS) (Dahlan, 2016).

On the other hand, Indonesia, inspired by Bangladesh, adopted a waqf bank model to manage waqf assets. This waqf bank is different from commercial banks. If banks are generally profit-oriented, they are different from waqf banks which are implemented in spite of all economic profit orientations and are fully dedicated to social welfare by providing financing for small businesses and focusing on the economic development of marginal communities.

The following is a scheme for managing and channeling the results of waqf money in the Waqf Bank model in Indonesia

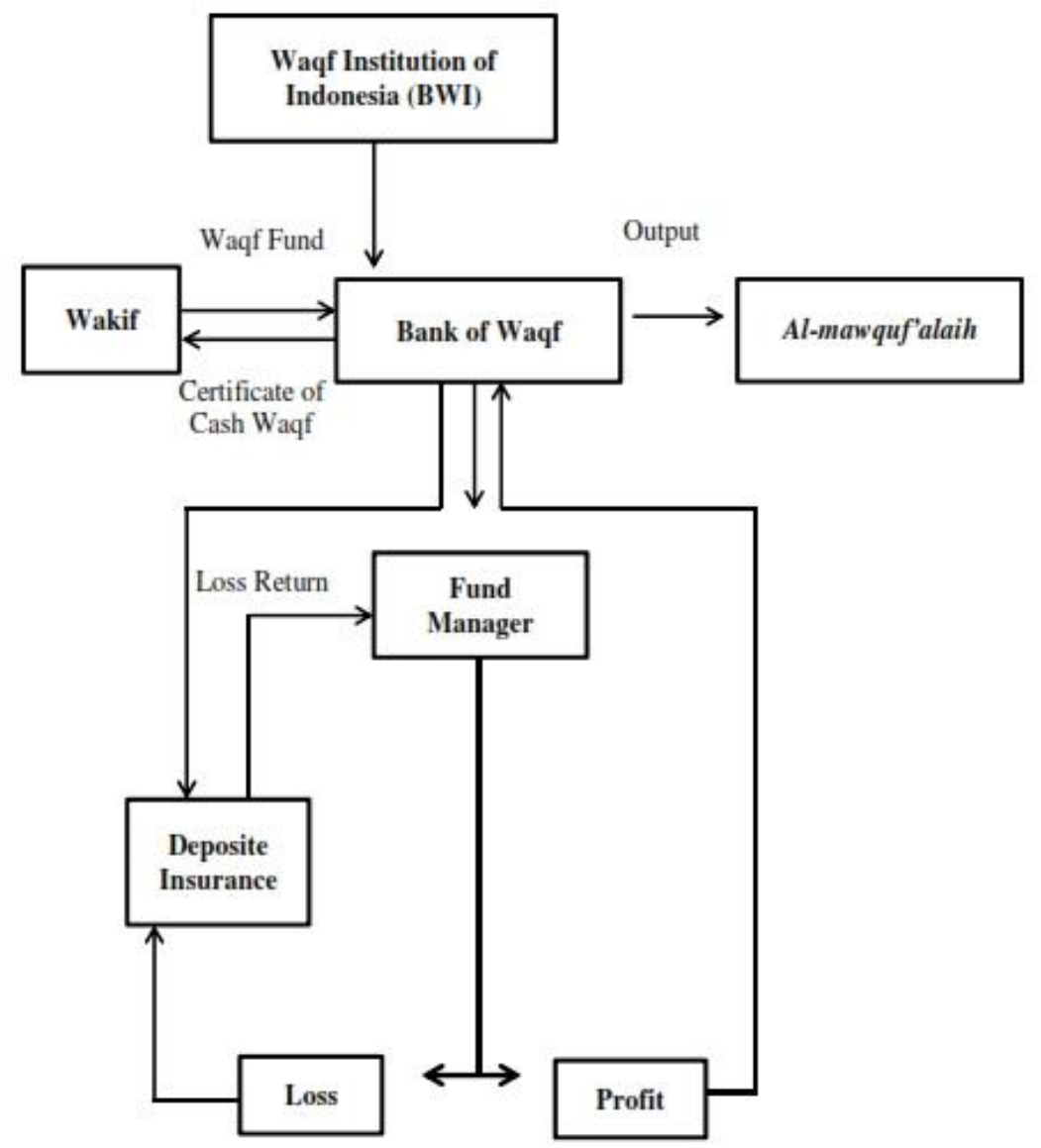

Figure 3. Model of Bank of Waqf in Indonesia Source: Havita, dkk, (2018).

This scheme shows the flow of waqf money applied. BWI remains central in managing waqf assets. Then BWI made a waqf bank in the management of waqf assets. The waqf bank has to interrogate the waqf with al-mauquf'alaih. Wakif donated wakaf money to the Waqf Bank, then the waqf bank issued a waqf certificate. when the funds have been collected, the waqf bank will manage it by channeling it to the community and channeling it to deposit insurance institutions. Waqf money that is managed has two possibilities, loss and profit. If it is a loss, it must report it to the deposit insurance agency. So the savings agency will compensate the bank for the waqf through the fund manager. If it is profitable, the funds will be returned to the waqf bank, and then distributed to al-mauquf'alaih.

On the bright side, the implementation of waqf banks has begun to be promoted by the OJK through Islamic boarding schools, which are named Micro Waqf Banks. The Micro 
Waqf Bank has the same scheme as the Waqf Bank model (Figure 3), only its orientation is more micro.

Associated with the conditions that will be faced by Indonesia, namely the demographic bonus, the above scheme (figure 3) will be able to be maximized. Moreover, until now literacy about waqf has not been spread evenly to the community. With the same waqf scheme, stakeholders and shareholders can be maximized in the lowest social processes. Thus, the potentials of waqf can be realized perfectly.

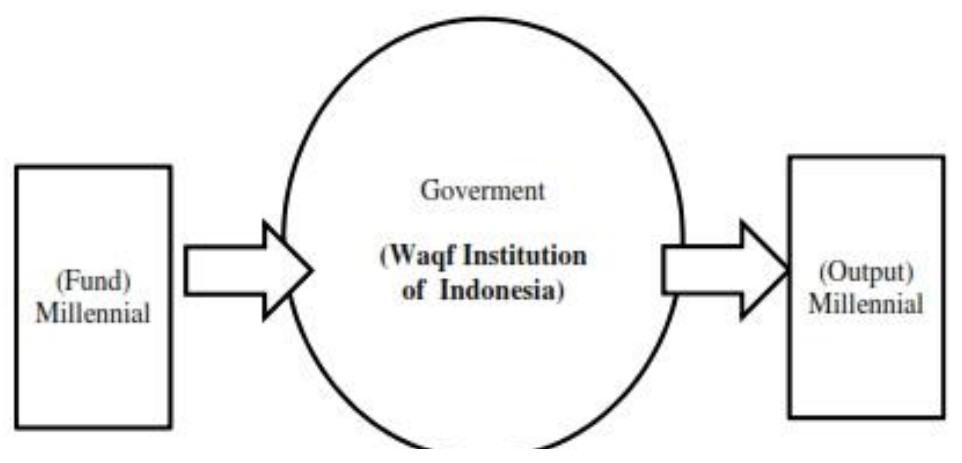

Figure 4. The Synergy of the government and the millennial Source: Processed Data

Figure 4 looks very simple, however, its implementation is not that simple. The synergy between the government and millennial greatly supports the development of waqf assets in Indonesia. Involving millennials from the collection process, management to the utilization process will greatly assist the government.

\section{Conclusion}

Indonesia will enter a favorable demographic bonus if it is linked to the application of waqf as a productive instrument. If so far, according to BPS (2018) as of 2018, the results of the inter-census population survey (SUPAS) of Indonesia's population reached 264.16 million. It is estimated that in 2045 the population will reach 318.96 million. With a productive population (15 - 64 years) reaching $65.2 \%$.

Waqf linked the Sukuk scheme in a press statement of the Ministry of Finance (2018), namely the Indonesian Waqf Board (BWI) as the manager of waqf funds investing waqf funds in State Sukuk. Furthermore, the return from the State Sukuk yields is channeled by BWI through the Nadzir Distribution Partners for social activities and for financing social infrastructure projects that will become endowments assets. At the maturity date of the Sukuk Negara, the repayment cash is returned by BWI to the endangers $100 \%$.

Another scheme of waqf in Indonesia is a Bank of Waqf. BWI remains central in managing waqf assets. Then BWI made a waqf bank in the management of waqf assets. The waqf bank has to interrogate the waqf with al-mauquf'alaih. Wakif donated waqf money to the Waqf Bank, then the waqf bank issued a waqf certificate. when the funds have been collected, the waqf bank will manage it by channeling it to the community and channeling it to deposit insurance institutions. Waqf money that is managed has two possibilities, loss and profit. If it is a loss, it must report it to the deposit insurance agency. So the savings agency will compensate the bank for the waqf through the fund manager. If it is profitable, the funds will be returned to the waqf bank, and then distributed to al-mauquf'alaih.

Associated with the conditions that will be faced by Indonesia, the demographic bonus, the above scheme (figure 3) will be able to be maximized. Moreover, until now literacy about 
waqf has not been spread evenly to the community. With the same waqf scheme, stakeholders and shareholders can be maximized in the lowest social processes. Thus, the potentials of waqf can be realized perfectly.

\section{Limitation}

This research is still less comprehensive. Even in its application in Indonesia, endowments of money implemented with linked Sukuk endowments are still relatively new. So it still needs evaluations in practice.

\section{Bibliography \\ Book/Journal/Thesis}

Atabik, Ahmad. (2014). Manajemen Pengelolaan Wakaf Tunai di Indonesia. Jurnal ZISWAF, Vo.1, No.1, Pp 82-107.

Bahmi, Muhammad Akbar. (2018). Sulaf (Sukuk Linked Waqf): Inovasi Sukuk Daerah melalui Optimalisasi Fungsi Tanah Wakaf menuju Pembangunan dan Pemerataan Infrastruktur dalam Refleksi Konsep Nawacita Jokowi-JK 2019. Skripsi Universitas Hasanuddin. Makassar: Universitas Hasanuddin.

Bank Indonesia. (2016). Wakaf: Pengaturan dan Tata Kelola yang Efektif. Jakarta: Departemen Ekonomi dan Keuangan Syariah.

Budiman, Mochammad Arif. (2014). The Significance of Waqf for Economic Development. Journal Equilibrium, Volume 2, No. 1.

Dahlan, Rahmat. (2016). Analisis Kelembagaan Badan Wakaf Indonesia. Esesni: Jurnal Bisnis dan Manajemen. Volume 6 (1), Pp. 113-124.

Fitri, Resfa, and Heni P. Wilantoro. (2018). Analysis of Problems' Solutions Priority in Managing Productive Waqf (Case Study of Banjarnegara District). Journal AlMuzara'ah, Vol.6, No.1, DOI: 10.29244/jam.6.1.41-59.

Gonzales, Eugenio M. (2003). Building and Managing Endowments: Lessons from Southeast Asia. Part of Series Produced with Support from the Sasakawa Peace Foundation.

Hamzah, Z. (2016). Analisis Faktor-Faktor yang Mempengaruhi Pengelolaan Wakaf di Kabupaten Bogor. Skripsi. Bogor: Institut Pertanian Bogor.

Hasan, Suhirman. (2010). Wakaf Uang dan Impelemntasinya di Indonesia. De Jure, Jurnal Syariah dan Hukum, Volume 2 Nomor 2, Pp. 162-177.

Havita, Gusva, Kartika Arum Sayekti, and Silvia Ranny Wafiroh. (2018). Model Bank Wakaf di Indonesia dalam Potensinya untuk Mengembangkan Wakaf Uang dan Mengatasi Kemiskinan.

Hayes, Adrian and Diahhadi Setyonaluri. (2015). Taking Advantage of The Demographic Dividend in Indonesia: a Brief Introduction to Theory and Practice. UNFPA. 
Norhaliza, B.M.N., and Mustafa Omar Mohammed. (2009). Categorized of waqf Land and Management Using Islamic Investment Models: The Case of The State of Selangor, Malaysia.

Puspitasari, Ajeng Wahyu. (2017). Optimizing Productive Land Waqf Towards Farmers Prosperity. Journal of Indonesian Applied Economics, Vol. 6 No.1, Pp. 103-112.

Saifuddin, F.B., et al. (2014). The Role of Cash Waqf in Poverty Alleviation: Case of Malaysia. Presented in Seminar Waqf Iqlimi, 28-42. Malaysia: Universitas Sains Islam Malaysia.

Shafii, Zurina, Zamir Iqbal, and Mustafa Tasdemir. (2015). Governance Regulatory Framework for Waqf in Selected Countries. Paper. The paper was written during the first author's visiting scholarship term in the world bank global Islamic Finance Development Centre, Borsa Istanbul, Turkey.

Siswantoro, Dodik. (2007). The Effectiveness of Waqf Fund Raising through Mutual Fund in Indonesia.

Tong, Goh Chok. (2007). Integration of Awqaf (Islamic Endowment) in Islamic Financial Sectors. Speech at the opening ceremony of the Singapore International Waqf Conference 2007, Singapore.

Yuliani, M. (2017). Strategi Optimalisasi Pengelolaan Wakaf di Indonesia. Skripsi. Bogor: Institut Pertanian Bogor.

\section{Aricle/Internet}

Kementerian Keuangan. (2018). Satu Dasawarsa Sukuk Negara untuk Kemashlahatan Bangsa. Keterangan Pers. No. 55/KLI/2018.

Katadata. (2018). 100 Tahun Indonesia Merdeka, Jumlah Penduduk Mencapai 319 Juta Jiwa. Retrieved by https://databoks.katadata .co.id/datapublish/2018/10/03/100-tahunindonesia-merdeka-jumlah-penduduk-mencapai-319-juta-jiwa 